\title{
CONDUCT DISORDERS IN EPILEPTIC CHILDREN
}

\author{
BY \\ F. GRUNBERG and D. A. POND \\ From the Maudsley Hospital and the Department of Clinical Neurophysiology, Institute of Psychiatry, \\ London, S.E.5
}

The management of epileptic children has greatly improved during the last 10 years with new methods of investigation, new anticonvulsant drugs, and sometimes neurosurgical procedures, but conduct disorders encountered in epileptic children remain a most intractable problem.

In spite of popular beliefs only a small proportion of epileptic children have severe disorders of this type. Henderson (1953) found that about $12 \%$ of a random sample of school-age epileptics were emotionally disturbed and badly behaved. Bridge (1949) found only $9 \%$ of severe disorders in his large clinic material though one-third were mildly disturbed. As in the case of adult epileptics, the favoured aetiological theories blame either physiological factors (leading to such concepts as the epileptic personality) or environmental factors such as parental mishandling. Pond (1952) considered that in fact both environmental and physiological factors had to be taken into account.

The object of this study was to investigate factors associated with conduct disorders in epileptic children and to compare them with conduct disorders in non-epileptic children.

\section{Material and Methods}

This study was based on the analysis of the case histories of 53 selected epileptic children with conduct disorders, 53 psychologically normal epileptic children, and 35 non-epileptic children with conduct disorders. They were all seen at the Children's Department of the Maudsley Hospital, and examined and investigated as reported by Pond (1952).

All the epileptic children had a clinical history of fits and a definite epileptic E.E.G. The non-epileptic children had no clinical history of paroxysmal loss of consciousness whatsoever and their E.E.G.s were normal for their age group. The psychologically normal epileptics did not present any significant emotional or behaviour problems. It was essential in such a study to form groups as homogeneous as possible and the criteria for selection were as follows.
Psychiatric Criteria.-The term " behaviour disorder" was not used here because conventionally this term implies a whole range of disturbances which were not considered in this investigation, which was restricted to conduct problems, i.e., those which are socially disturbing, as opposed to personality problems, which are more specifically related to the child himself. Conduct disorders were more easily elicited objectively and were usually a major complaint if severe and persistent. They included aggressive manifestations, such as severe and frequent temper tantrums, destructiveness, fighting, etc., truanting and wandering, lying and stealing. In other words, only children who came into conflict with society whether in the family or outside were selected, although an overlapping with other types of disorders, such as neurotic symptoms or enuresis, was inevitable. Nevertheless, cases where neurotic symptoms, such as severe obsessions, anxiety, depression, dominated the clinical picture, were excluded from the investigation.

Physical Criteria.-Children with severe physical handicaps as well as epilepsy (e.g., infantile hemiplegias) were excluded because such disabilities in themselves may produce social and psychological problems.

Social Criteria.-All the selected children when seen at the clinic were living at home, with at least one relative, and were all attending day schools for normal or educationally subnormal children. Children in boarding schools and institutions were excluded.

Intelligence Criteria.-All the selected children had intelligence tests. Severe mental defectives were excluded but children with I.Q.s as low as 65 were considered if they were attending day schools for educationally subnormal children at the time of examination.

\section{Evaluation of Aetiological Factors}

The three groups of children were compared under three sets of factors: organic, genetic, and social, 
which had been elicited in the history of each case. The statistical technique was the $\chi^{2}$ test.

Organic Factors.-They include: (a) natal and post-natal brain injuries characterized by difficult or protracted labour, damage done through instrumental delivery or breech extraction, post-natal head injuries sufficiently severe to cause some loss of consciousness after the accident, and sometimes postconcussional symptoms; $(b)$ all forms of meningitis were considered but only clinically typical cases of encephalitis were included.

Genetic Factors.-The family history of the children was investigated for evidence of psychosis, neurosis, psychopathy (including severe alcoholism), and epilepsy in parents, siblings, paternal and maternal grandparents.

Environmental Social Factors. - The disturbances in the maternal or paternal (or substitutes') attitude towards the child, including the rejecting mothers showing overt hostility or neglect, were studied, also the rigid perfectionist and the over-protective, over-solicitous mother.

Sibling Rivalry.-This was defined as a disturbed emotional relationship between the patient and at least one of his brothers or sisters.

Restriction.-This refers to parental attitudes or to the material environment, i.e., when the child was deprived of the normal social opportunities of a child of his age.

Breaks and Changes in Environment.-These were observed in cases where the family led a nomadic existence or in cases where the child was often sent to live with other relatives or even in institutions for a time.

Marital disharmony among parents was another factor.

Such information is routinely obtained in the histories of all children seen at the Maudsley Child Guidance Clinic.

\section{Results}

Tables I and II show the results in 53 epileptic children (Group A) with and 53 without conduct disorders (Group B). The groups were homogeneous but not exactly matched. Their ages ranged from 5 to 16 years and the I.Q.s from 65 to 130 , ascertained by the Wechsler-Bellevue or Stanford-Binet tests.

Table I shows that there were no significant differences between the two groups in respect of personal history of any form of brain damage. As regards genetic factors only a family history of
TABLE I

ORGANIC AND GENETIC FACTORS IN EPILEPTIC CHILDREN

\begin{tabular}{|c|c|c|c|c|c|}
\hline Factors & $\begin{array}{c}53 \text { Children } \\
\text { with } \\
\text { Conduct } \\
\text { Disorders } \\
\text { (Group A) }\end{array}$ & $\begin{array}{c}53 \text { Children } \\
\text { without } \\
\text { Conduct } \\
\text { Disorders } \\
\text { (Group B) }\end{array}$ & $\begin{array}{l}\text { Differ- } \\
\text { ence }\end{array}$ & $x^{2}$ & $\mathbf{P}$ \\
\hline $\begin{array}{l}\text { Prenatal and post- } \\
\text { natal cerebral } \\
\text { damage }\end{array}$ & 13 & 8 & 5 & - & - \\
\hline $\begin{array}{l}\text { Meningitis-encepha- } \\
\text { litis }\end{array}$ & 6 & 6 & - & - & - \\
\hline $\begin{array}{l}\text { Psychosis in the } \\
\text { family }\end{array}$ & 5 & 5 & - & - & - \\
\hline $\begin{array}{l}\text { Neurosis in the } \\
\text { family }\end{array}$ & 13 & 9 & 4 & - & - \\
\hline $\begin{array}{l}\text { Psychopathy in the } \\
\text { family }\end{array}$ & 12 & 2 & 10 & 7 & 0.01 \\
\hline $\begin{array}{l}\text { Epilepsy in the } \\
\text { family }\end{array}$ & 10 & 11 & -1 & - & - \\
\hline
\end{tabular}

psychopathy reached a significantly greater incidence $\vec{\circ}$ at the $10 \%$ level in the children with conduct $\overrightarrow{\vec{\omega}}$ disorders.

In contrast Table II shows several significant en- $\overline{\bar{V}}$ vironmental differences. The greatest differences 0 were in maternal attitude and in breaks and changes in environment, but all the other factors investigated showed less marked differences.

TABLE II SIGNIFICANT ENVIRONMENTAL FACTORS IN EPILEPTIE CHILDREN

\begin{tabular}{|c|c|c|c|c|c|}
\hline Factors & $\begin{array}{l}53 \text { Child- } \\
\text { ren with } \\
\text { Conduct } \\
\text { Disorders } \\
\text { (Group A) }\end{array}$ & $\begin{array}{l}53 \text { Child- } \\
\text { ren without } \\
\text { Conduct } \\
\text { Disorders } \\
\text { (Group B) }\end{array}$ & $\begin{array}{c}\text { Differ- } \\
\text { ence }\end{array}$ & $x^{2}$ & $\mathbf{P}$ \\
\hline Maternal atti- & 34 & 10 & 14 & $22 \cdot 6$ & 0.001 \\
\hline $\begin{array}{l}\text { tude disturbed } \\
\text { Paternal atti- } \\
\text { tude disturbed }\end{array}$ & 17 & 6 & 11 & $5 \cdot 2$ & $0.05-0.02$ \\
\hline $\begin{array}{l}\text { Sibling rivalry } \\
\text { Marital dishar- } \\
\text { mony among } \\
\text { parents }\end{array}$ & $\begin{array}{l}10 \\
14\end{array}$ & $\begin{array}{l}2 \\
4\end{array}$ & $\begin{array}{r}8 \\
10\end{array}$ & $\begin{array}{l}5 \cdot 2 \\
5 \cdot 4\end{array}$ & $\begin{array}{r}0.05-0.02 \\
0.02\end{array}$ \\
\hline $\begin{array}{l}\text { Restriction at } \\
\text { home }\end{array}$ & 9 & 1 & 8 & 6.4 & $0.02-0.01$ \\
\hline $\begin{array}{l}\text { Breaks a n d } \\
\text { changes in en- } \\
\text { vironment }\end{array}$ & 14 & 1 & 13 & 11 & 0.001 \\
\hline
\end{tabular}

Tables III and IV show the results in 35 epileptic children (Group C) with conduct disorders and in 35 non-epileptic children with conduct disorders (Group D); their ages ranged from 5 to 15 years and I.Q.s from 76 to 130 . These groups were $ᄋ$ exactly matched for age, sex, and intelligence. 2 Group $C$ is smaller than Group A because of the 을 difficulty in obtaining exactly matching pairs, but $\triangle$ the tables show that the smaller is not different from the larger in any important way.

Table III shows no difference in organic factors in $\%$ the personal history and only a slightly significant $\tilde{\sim}$ difference in the family history of epilepsy. 
TABLE III

ORGANIC AND GENETIC FACTORS IN CHILDREN WITH CONDUCT DISORDERS

\begin{tabular}{|c|c|c|c|c|c|}
\hline Factors & $\begin{array}{l}35 \text { Epileptic } \\
\text { Children } \\
\text { with } \\
\text { Conduct } \\
\text { Disorders } \\
\text { (Group C) }\end{array}$ & $\begin{array}{l}\text { 35 Non- } \\
\text { epileptic } \\
\text { Children } \\
\text { with } \\
\text { Conduct } \\
\text { Disorders } \\
\text { (Group D) }\end{array}$ & $\begin{array}{l}\text { Differ- } \\
\text { ence }\end{array}$ & $x^{2}$ & $\mathbf{P}$ \\
\hline $\begin{array}{l}\text { Prenatal and post- } \\
\text { natal cerebral } \\
\text { damage }\end{array}$ & 9 & 6 & 2 & - & - \\
\hline $\begin{array}{l}\text { Meningitis- } \\
\text { encephalitis }\end{array}$ & 3 & 3 & - & - & - \\
\hline $\begin{array}{l}\text { Psychosis in the } \\
\text { family }\end{array}$ & 4 & 2 & 2 & - & - \\
\hline $\begin{array}{l}\text { Neurosis in the } \\
\text { family }\end{array}$ & 10 & 14 & -4 & - & - \\
\hline $\begin{array}{l}\text { Psychopathy in } \\
\text { the family }\end{array}$ & 9 & 8 & 1 & - & - \\
\hline $\begin{array}{c}\text { Epilepsy in the } \\
\text { family }\end{array}$ & 10 & 3 & 7 & 3.8 & 0.05 \\
\hline
\end{tabular}

Table IV shows that as regards environmental factors there were no significant differences at all between the two groups.

TABLE IV

ENVIRONMENTAL AND SOCIAL FACTORS IN CHILDREN WITH CONDUCT DISORDERS

\begin{tabular}{l|c|c|c|c|c}
\hline Factors & $\begin{array}{c}35 \text { Epileptic } \\
\text { Children } \\
\text { with } \\
\text { Conduct } \\
\text { Disorders } \\
\text { (Group C) }\end{array}$ & $\begin{array}{c}\text { 35 Non- } \\
\text { epileptic } \\
\text { Children } \\
\text { with } \\
\text { Conduct } \\
\text { Disorders }\end{array}$ & $\begin{array}{c}\text { Differ- } \\
\text { ence } \\
\text { (Group D) }\end{array}$ & $x^{2}$ & P \\
\hline $\begin{array}{c}\text { Maternal attitude } \\
\text { disturbed }\end{array}$ & 25 & 27 & -2 & - & - \\
$\begin{array}{c}\text { Paternal attitude } \\
\text { disturbed }\end{array}$ & 12 & 15 & -2 & - & - \\
$\begin{array}{c}\text { Sibling rivalry } \\
\text { Marital dishar- } \\
\text { mony }\end{array}$ & 10 & 11 & -4 & - & - \\
$\begin{array}{c}\text { Restriction at } \\
\text { home }\end{array}$ & 7 & 14 & -4 & - & - \\
$\begin{array}{c}\text { Breaks and change } \\
\text { in environment }\end{array}$ & 13 & 15 & -2 & - & - \\
\hline
\end{tabular}

\section{Discussion and Conclusion}

This study revealed that only unfavourable social environmental factors were significantly associated with disorders of conduct, the most significant being a disturbed attitude of the mother towards the child and experiences of breaks and changes in environment during the child's life. Cerebral organic factors without neurological sequelae, or a history of psychosis, neurosis, and epilepsy in the family were not found to be specifically associated with conduct disorders. Psychopathy in the family, which was investigated as a genetic factor in the aetiology of conduct disorders in epileptic children, might well have operated as an environmental factor. The correlations in the epileptics (Groups A and B) are in accordance with those of Bridge (1949) who found that personality disorders were more highly correlated only with environmental factors and not with brain damage. On the other hand, when epileptic and non-epileptic children (Groups $\mathrm{C}$ and D) with conduct disorders were compared there was no significant difference in the three sets of factors apart from the incidence of epilepsy in the family, which was higher in the epileptics (Group C) as expected. The surprising absence of significant differences in the incidence of cerebral trauma and infection in the two groups might have been due to a selection bias, because it was essential for the purpose of the investigation to select non-epileptic children with normal E.E.G.s to exclude all possible organic factors in this group. Electroencephalographic examinations are not carried out routinely in child guidance cases but are usually requested when an organic factor is suspected. This explains why the selected non-epileptic group might have been overweighed by suspected organic factors.

When environmental social factors were examined, epileptics and non-epileptics with conduct disorders had very similar backgrounds. Both groups suffered from disturbed parental emotional attitudes, sibling rivalry, marital disharmony of parents, restriction, and breaks and changes in environment. These findings suggest a causal relationship between conduct disorders and disturbed social background in epileptic children. Moreover, Henderson's and Bridge's incidence of behaviour and personality disorders in epileptic children corresponds roughly to estimates of the proportion of all psychiatric disorders in the total child population. Such a distribution could result either from factors within the child or from factors within the parents such as their mishandling leading to maladjustment. Epilepsy in one of the children constitutes an added stress in any family. Such a child must certainly strain the mother's resources. There is no doubt that a woman who is not yet emotionally adequate for maternity would be further disturbed were her child epileptic. On the other hand, a normal woman who has an epileptic child would probably tend to be more over-protective, anxious, and restrictive. This was corroborated by Navratil and Strotzka (1954) who gave a maternal attitude questionnaire to 100 mothers of epileptic childern and a control group of 100 mothers of normal children. From their investigation it was clear that the mothers of epileptic children were more over-protective and anxious, and there was a striking difference between the two groups on questions dealing with guilt and selfreproach. The authors concluded that the mothers of epileptic children had a tendency to be of the " compensatory over-protective" type.

Pond and Bidwell (1954) have discussed (with case histories) the treatment of the whole family situation, and especially the problems of the mother, that is 
often necessary for the relief of the behaviour disorder of the child.

The plan of this investigation did not permit of any separate study of different types of epilepsy, as discussed by Pond (1952) and more intensively by Nuffield (in press). Likewise, the investigation can give no data for or against the existence of the socalled " epileptic personality", or any specific traits seen only or mainly in epileptic children as described by Bradley (1951). There is no doubt that different forms of epilepsy are associated with different personality reactions and behaviour disorders, but whether all epileptics have traits in common is less certain.

The main conclusion to be drawn from this study is that conduct disorders in epileptic children cannot be properly investigated or treated save by the methods of child psychiatry which alone can make a full study of the emotional development of the child and its relation to the social milieu. Such investigations are as necessary as the medical and physiological studies needed to diagnose the type and cause of the actual epileptic attacks.

\section{Summary}

Fifty-three epileptic children with conduct disorders were compared with 53 psychiatrically normal epileptic children in respect of three sets of factors: organic, genetic, and social environmental. A $\chi^{2}$ statistical analysis revealed that the two groups differed significantly as to their social environment. The epileptic children with conduct disorders had a more disturbed family background. The most significant social environmental factors were a disturbed emotional maternal attitude towards the child and experiences by the child of breaks and changes in environment.

When 35 epileptic children with conduct disorders were compared with 35 non-epileptic children with the same behaviour problems, the sameadverse social environmental factors were found in both groups. Although an association between conduct disorders in childhood epilepsy and an adverse social background was demonstrated in this study, the authors conclude that no causal relationship between an unfavourable social environment and conduct disorders in epilepsy has been established. Other factors such as the nature of the "epileptic process" and the effect of the epilepsy on the environment were not considered. The disturbed family background associated with conduct disorders in childhood epilepsy, whether causal or not, must be dealt with by combined medical and child guidance techniques.

\section{REFERENCES}

Bradley, C. (1951). J. Amer. med. Ass., 146, 436. Bridge, E. M. (1949). Epilepsy and Convulsive Disorders in Children McGraw-Hill, New York.

Henderson, P. (1953). Brit. J. prev. soc. Med., 7, 9.

Navratil, L., and Strotzka, H. (1954). Wien. Arch. Psychol., 4, 36

Pond, D. A. (1952). J. ment. Sci., 98, 404. 